\title{
Anti-Microbial Study of Shwasakuthar Rasa: In Vitro Study
}

\author{
Research article
}

Das Subroto Kumar ${ }^{1}$, Yadav Kapil Deo ${ }^{2 *}$, Dubey SD $^{3}$, Reddy KRC ${ }^{4}$

1. Post graduate Diploma in Ayurvedic drugs standardization scholar, Dept. of Dravya guna 2. Junior Resident, Department of Rasa Shastra.

3. Professor, Dept. of Dravyaguna, 4. Associate Professor, Department of Rasa Shastra, Faculty of Ayurveda, IMS, BHU, Varanasi.

\begin{abstract}
Shwasa kuthar Rasa is well known drug used in Respiratory disorders in Indian System of Medicine. It is herbomineral formulation made up of Parada, Gandhaka, Vatsanabha, Tankana, Manashila, Maricha, Pippali, Sunthi by triturating in Tambula patra Swarasa and indicated in Shwasa, Kasa, Mandagni, disorders prominent in Vata-Shleshma doshas. These action of Shwas kuthar rasa may be due to its antimicrobial activity, so that in vitro antimicrobial activity was assessed by Agar Disc Diffusion method with reference to staphylococcus aureus. In-vitro tests are necessary to help determine initial dose-response data as well as to evaluate potential susceptibility and/or resistance of specific pathogens. Invitro systems include the ability to control the number of bacteria, extent of antimicrobialbacteria contact time, as well as the influence of various environmental factors, such as oxygen tension, $\mathrm{pH}$, and temperature. Agar dilution methods are to determine the lowest concentration of the assayed Shwas kuthar rasa as antimicrobial agent (minimal inhibitory concentration, MIC) that, under defined test conditions, inhibits the visible growth of the bacterium being investigated. MIC values are used to determine susceptibilities of bacteria to drugs and also to evaluate the activity of new antimicrobial agents.
\end{abstract}

Key words: Shwas kuthar rasa, Minimal inhibitory concentration

\section{Introduction}

"Health for all by the year $2000 "$ is both a goal and a process which engages each nation of the world to improve the health of its people. This concept calls for a level of health that will permit all people to lead a socially and economically productive life. The success of any health system depends on the ready availability

\footnotetext{
*Corresponding Author:

Yadav Kapil Deo,

Junior Resident,

Department of Rasa Shastra,

Faculty of Ayurveda,

IMS, BHU,

Varanasi.

E-mail: k.d.yadav1983@gmail.com
}

and use of suitable drugs on a sustainable basis. Medicinal plants have always played a key role in world of health. WHO has also done its share to further awareness of the importance of traditional medicines to the majority of world's population, and to promote increased rational exploitation for all present and future peoples of the world of safe and effective practices, including the use of medicinal plants Since the discovery and use of sulpha drugs, antibiotics such as penicillin's and synthetic drugs, there has been a dramatic decline in the popularity of medicinal plants in therapy. In a number of cases, these synthetic drugs have caused side effects or adverse reactions that were not fore seen in preclinical and clinical 
examinations. As a result, a resurgence of interest in the study and use of medicinal herbomineral formulation has been taken place during the last two decades. As a result of modern isolation techniques and pharmacological testing procedures, herbomineral formulation found their way into modern medicine as purified substances rather than in the form of galenical preparations. One of the major problems encountered with the use of natural products, is maintaining product uniformity. Furthermore, plants and metals and minerals are valuable for modern medicine in four basic ways ${ }^{1}$

- They are used as sources of direct therapeutic agents.

- They serve as raw materials base for elaboration of more complex semi synthetic chemical compounds

- The chemical structures derived from plant sources, metals and minerals can be used as models for new synthetic compounds.

The systematic investigation of drugs used in indigenous medicines on modern scientific line has brought into prominence, the merits and qualities of certain drugs and it has been shown that, if brought into general use they may prove to be very valuable addition to the present armamentarium of the medical man to relieve the sufferings of humanity ${ }^{2}$. Shwas kuthar $\mathrm{rasa}^{3}$ is an important formulation in Indian system of Medicine which is used in various disorders like Shwas, Kasa,
Mandagni, disorders prominent in VataShleshma doshas as well as in pleurisy. Anti microbial agent are the prime source of these disorders specially pleurisy. No detailed Pharmacological studies have been done on Shwas kuthar rasa, but however some phytochemical and pharmacological studies were carried out on the plants, metals and minerals used in preparation of it like anti fungal activity of gandhak rasayana ${ }^{4}$, anti inflammatory activity of Piper longum ${ }^{5}$ and Sunthi ${ }^{6}$ but effect on whole compound formulation studied on microbial activity was known.

\section{Procurement of Ingredients}

The entire drug needed for preparation of Shwas kuthar rasa was collected from local market of Varanasi.

\section{Pharmaceutical process of Shwas kuthar rasa}

Plant material like Maricha, Pippali and Sunthi were dried in sunlight and made in to fine powder. Parada, Gandhaka,Manashila and Vatsanabh was used after shodhan process (Details are mentioned in table 1). Kajjali was prepared with Sudha Parada and Sudha Gandhaka by trituration process. Then the powder, which was prepared from Sunthi, Maricha and Pippali was incorporated in Kajjali and mixed uniformaly. The above materials was triturated with Adrak swarasa for three days and made in to vati equal to one ratti ${ }^{7}$.

Table 1: Showing details about ingredients of Shwas kuthar rasa

\begin{tabular}{|l|l|l|l|}
\hline S. No. & Name of Drugs & Drugs used for Shodhana & Process of Shodhana \\
\hline 1 & Parada & Lime, Saindhav, Nistush Rasona & Mardana and Prakshalana \\
\hline 2 & Gandhaka & Go-Dugdha & Swedana \\
\hline 3 & Manashila & Adhraka & Bhawana \\
\hline 4 & Vatsanabha & Go- Mutra & Swedhana \\
\hline
\end{tabular}

\section{Materials and Methods}

In vitro study of Shwas kuthar rasa

was studies against staphylococoous aureus by using Agar disc diffusion method. In this study Ciprofloxacin was used as standarded drug. 


\section{Agar Disc Diffusion method}

In vitro antibacterial study of Shwas kuthar rasa was performed by disc diffusion method. The agar diffusion test ${ }^{8}$, was used for measuring the effect of an antimicrobial agent against bacteria grown in culture. A filter-paper disk, impregnated with the Shwas kuthar rasa was placed on the surface of the agar.

The Shwas kuthar rasa diffuses from the filter paper into the agar. The concentration of the Shwas kuthar rasa was highest next to the disk, and decrease as distance increase from the disk. Different strains of Staph. aureus were grown on plate using Mueller Hinton as growth media9. Mueller Hinton agar plate was used for susceptibility testing for all organism, except those which need blood or altered blood for growth. For preparing the test plate, prepare the medium as described on manufacturers instruction, cool down at $50{ }^{\circ} \mathrm{C}$, pour in large size petri dishes to a uniform depth of $4 \mathrm{~mm}$, then allow the plates to solidify at room temperature. Just prior to use we dried the culture plates in an incubator at $35{ }^{\circ} \mathrm{C}$ with lid partly open then inoculate the plates within 15 minutes after preparing the inoculum. With a wax pencil we divided the plate in to section according to number of no. of groups in study and labelled the plate with identification number. A Dip sterile cotton swabs rub gently over the plate in several direction to obtain uniform distribution of inoculums. Press the disc in to agar to ensure complete contact. Inoculate the plates overnight at $37{ }^{\circ} \mathrm{C}$, under appropriate condition, suitable for staphylococoous aureus. Following inoculation, we measured the diameter of zone of inhibition of growth by using of callipers.

\section{Result}

Out of four strains, Shwas kuthar rasa showed effect on three strains. In one strains Shwas kuthar rasa do not shows any activity. Details about observation are mentioned in Table 2 3.

Table2: showing results of Shwas kuthar rasa on organism by agar disc diffusion method

\begin{tabular}{|l|l|l|l|l|l|}
\hline \multicolumn{2}{|l|}{ S.No. } & Organism & \multicolumn{4}{|l|}{ Dilutions of Shwas kuthar rasa in different concentrations } \\
\hline \multicolumn{2}{|l|}{} & $300 \mathrm{mg} / \mathrm{dl}$ & $400 \mathrm{mg} / \mathrm{dl}$ & $500 \mathrm{mg} / \mathrm{dl}$ & $600 \mathrm{mg} / \mathrm{dl}$ \\
\hline 1 & Staph. aureus $1^{\text {st }}$ strain & $\mathrm{M}$ & $\mathrm{M}$ & $\mathrm{M}$ & $\mathrm{M}$ \\
\hline 2 & $\begin{array}{l}\text { Staph. } \\
\text { strain }\end{array}$ & $\mathrm{S}$ & $\mathrm{S}$ & $\mathrm{S}$ \\
\hline 3 & Staph. aureus 3 $^{\text {rd }}$ strain & $\mathrm{M}$ & $\mathrm{M}$ & $\mathrm{M}$ & $\mathrm{M}$ \\
\hline 4 & $\begin{array}{l}\text { Staph. aureus } 4^{\text {th }} \\
\text { strain }\end{array}$ & $\mathrm{R}$ & $\mathrm{R}$ & $\mathrm{R}$ & $\mathrm{R}$ \\
\hline
\end{tabular}

S: Sensitive (Inhibition zone > $12 \mathrm{~mm}$ ), M: Moderate Sensitive (Inhibition zone 7-12 mm), R: Resistant (Inhibition zone $<7 \mathrm{~mm}$ )

Table 3: showing results of Ciprofloxacin (Standard drug) on organism by agar disc diffusion method

\begin{tabular}{|l|l|l|l|l|l|}
\hline \multicolumn{2}{|l|}{ S.No. } & Organism & \multicolumn{4}{|l|}{ Dilutions of Ciprofloxacin in different concentrations } \\
\hline \multicolumn{2}{|l|}{} & $300 \mathrm{mg} / \mathrm{dl}$ & $400 \mathrm{mg} / \mathrm{dl}$ & $500 \mathrm{mg} / \mathrm{dl}$ & $600 \mathrm{mg} / \mathrm{dl}$ \\
\hline 1 & Staph. aureus $1^{\text {st }}$ strain & S & S & S & S \\
\hline 2 & $\begin{array}{l}\text { Staph. aureus } 2^{\text {nd }} \\
\text { strain }\end{array}$ & S & S & S & S \\
\hline 3 & Staph. aureus $3^{\text {rd }}$ strain & S & S & S & S \\
\hline
\end{tabular}




\begin{tabular}{|l|l|l|l|l|l|}
\hline 4 & $\begin{array}{l}\text { Staph. aureus } 4^{\text {th }} \\
\text { strain }\end{array}$ & $\mathrm{S}$ & $\mathrm{S}$ & $\mathrm{S}$ & $\mathrm{S}$ \\
\hline
\end{tabular}

S: Sensitive (Inhibition zone $>12 \mathrm{~mm}$ )

Table 4: showing Minimum inhibitory concentration values of Shwas kuthar rasa on organism in different concentration

\begin{tabular}{|l|l|l|l|l|l|l|l|l|l|l|}
\hline $\begin{array}{l}\text { S.N } \\
\cdot\end{array}$ & $\begin{array}{l}\text { Micro } \\
\text { organism }\end{array}$ & $\begin{array}{l}600 \\
\mathrm{mg} / \mathrm{m} \\
1\end{array}$ & $\begin{array}{l}300 \\
\mathrm{mg} / \mathrm{m} \\
1\end{array}$ & $\begin{array}{l}150 \\
\mathrm{mg} / \mathrm{m} \\
1\end{array}$ & $\begin{array}{l}75 \\
\mathrm{mg} / \mathrm{m} \\
1\end{array}$ & $\begin{array}{l}37 \\
\mathrm{mg} / \mathrm{m} \\
1\end{array}$ & $\begin{array}{l}18.5 \\
\mathrm{mg} / \mathrm{m} \\
1\end{array}$ & $\begin{array}{l}9.25 \\
\mathrm{mg} / \mathrm{m} \\
1\end{array}$ & $\begin{array}{l}4.5 \\
\mathrm{mg} / \mathrm{m} \\
1\end{array}$ & $\begin{array}{l}2.25 \\
\mathrm{mg} / \mathrm{m} \\
1\end{array}$ \\
\hline 1 & $\begin{array}{l}\text { Staph. } \\
\text { aureus }\end{array}$ & $\mathrm{S}$ & $\mathrm{S}$ & $\mathrm{S}$ & $\mathrm{S}$ & $\mathrm{S}$ & $\mathrm{S}$ & $\mathrm{S}$ & $\mathrm{R}$ & $\mathrm{R}$ \\
\hline 2 & E.coli & $\mathrm{S}$ & $\mathrm{S}$ & $\mathrm{S}$ & $\mathrm{S}$ & $\mathrm{S}$ & $\mathrm{S}$ & $\mathrm{S}$ & $\mathrm{R}$ & $\mathrm{R}$ \\
\hline 3 & $\begin{array}{l}\text { Pseudomon } \\
\text { as }\end{array}$ & $\mathrm{S}$ & $\mathrm{S}$ & $\mathrm{S}$ & $\mathrm{S}$ & $\mathrm{R}$ & $\mathrm{R}$ & $\mathrm{R}$ & $\mathrm{R}$ & $\mathrm{R}$ \\
\hline 4 & $\begin{array}{l}\text { S.typhimeru } \\
\text { m }\end{array}$ & $\mathrm{S}$ & $\mathrm{S}$ & $\mathrm{S}$ & $\mathrm{S}$ & $\mathrm{S}$ & $\mathrm{S}$ & $\mathrm{S}$ & $\mathrm{S}$ & $\mathrm{R}$ \\
\hline 5 & Morganella & $\mathrm{S}$ & $\mathrm{S}$ & $\mathrm{S}$ & $\mathrm{R}$ & $\mathrm{R}$ & $\mathrm{R}$ & $\mathrm{R}$ & $\mathrm{R}$ & $\mathrm{R}$ \\
\hline 6 & Shingella & $\mathrm{S}$ & $\mathrm{S}$ & $\mathrm{S}$ & $\mathrm{S}$ & $\mathrm{S}$ & $\mathrm{S}$ & $\mathrm{R}$ & $\mathrm{R}$ & $\mathrm{R}$ \\
\hline 7 & $\begin{array}{l}\text { Kleb. } \\
\text { Pneumoniae }\end{array}$ & $\mathrm{R}$ & $\mathrm{R}$ & $\mathrm{R}$ & $\mathrm{R}$ & $\mathrm{R}$ & $\mathrm{R}$ & $\mathrm{R}$ & $\mathrm{R}$ & $\mathrm{R}$ \\
\hline 8 & Serratia & $\mathrm{S}$ & $\mathrm{S}$ & $\mathrm{R}$ & $\mathrm{R}$ & $\mathrm{R}$ & $\mathrm{R}$ & $\mathrm{R}$ & $\mathrm{R}$ & $\mathrm{R}$ \\
\hline
\end{tabular}

S: Sensitive (Inhibition zone $>12 \mathrm{~mm}$ ), R: Resistant (Inhibition zone $<7 \mathrm{~mm}$ )

\section{Discussion}

Shwas kuthar rasa prepared by Parada, Gandhaka, Vatsanabh, Tankana, Manashila, Maricha, Pippali, Sunthi by triturating in Tambula patra Swarasa. Mercurial products show synergistic action when combined with other Plants, metals and minerals. In this preparation Pippali ${ }^{10}$, Sunthi ${ }^{11}$, and Gandhak ${ }^{4}$ were reported as antibacterial effect. By keeping these thing we studied antibacterial activity of Shwas kuthar rasa in different species bacterial as well as same bacteria with different strains and using ciprofloxacin as standard drug.

In Agar diffusion method, if the compound is effective against bacteria at a certain concentration, no colonies will grow where the concentration in the agar is greater than or equal to the effective concentration. This is the zone of inhibition. Thus, the size of the zone of inhibition is a measure of the compound's effectiveness: the larger the clear area around the filter disk, the more effective the compound. In above study we found that zone of inhibition for $2^{\text {nd }}$ strains of
Staph. aureus was> $12 \mathrm{~mm}$, this shows that Shwas kuthar rasa was significantly effective against $2^{\text {nd }}$ strains of Staph. aureus. Zone of inhibition for $1^{\text {st }}$ and $3^{\text {rd }}$ strain of bacteria was in between 7-12 mm, this indicate that Shwas kuthar rasa was moderately effective against $1^{\text {st }}$ and $3^{\text {rd }}$ strain of bacteria but Standard drug showed more than $12 \mathrm{~mm}$ of zone of inhibition, this indicate that standard drug was effective against all strains of bacteria. Our test drug was effective but Standard drug was more effective. We further studied that effect of dilution of Shwas kuthar rasa on different species of bacteria to find minimum inhibitory concentration. We find that minimum inhibitory concentration of test drug towards S.typhimerum, Pseudomonas, Morganella, Shingella, Serratia, Staph. aureus and E.coli was $4.5 \mathrm{mg} / \mathrm{ml}, 75 \mathrm{mg} / \mathrm{ml}, 150$ $\mathrm{mg} / \mathrm{ml}, \quad 18.5 \mathrm{mg} / \mathrm{ml}, 300 \mathrm{mg} / \mathrm{ml}$ and $9.25 \mathrm{mg} / \mathrm{ml} \quad$ respectively. Kleb. Pneumoniae was inhibited by any con centration of Shwas kuthar rasa. 


\section{Conclusion}

Shwas kuthar rasa effective against only three strains of Stah. aureus. and one strain did not show any effect of it. This shows that Shwas kuthar rasas was effective against only thrird strain of Staph. aureus. Shwas kuthar rasa shows different minimum inhibitory concentration on different species of bacteria like S.typhimerum, Pseudomonas, Morganella, Shingella, Serratia, Staph. aureus and E.coli was $4.5 \mathrm{mg} / \mathrm{ml}, 75$ $\mathrm{mg} / \mathrm{ml}, \quad 150 \mathrm{mg} / \mathrm{ml}, \quad 18.5 \mathrm{mg} / \mathrm{ml}, 300$ $\mathrm{mg} / \mathrm{ml}$ and $9.25 \mathrm{mg} / \mathrm{ml}$ respectively.

\section{References}

1. Jayarama Reddy et al. In vitro studies on anti asthmatic, analgesic and anti convulsant activities of the medicinal plant.

2. Chopra R.N.et al. (1976) Chopra's Indigenous Drugs of India. 2nd ed. U. N. Dhur and Sons Private Ltd., Calcutta, 61-3.

3. Bhaishjya Ratnavali Govind das sen edited by Brahma Shankar mishra Vidyotini hindi commentary by Kaviraj Ambica Dutta Shastri, Chaumbha Prakashan, Varanasi

4. Prasanna Kumar $\mathrm{T}$ et al. in-vitro antifungal activity of gandhak rasayana
International Journal of Ayurvedic Medicine, Vol 1, No 2 (2010)

5. Sharma A and Singh R Screening of anti inflammatory activity of certain indigenous drug on carrageenin induced hind paw oedema in rat, Bull. Med. Ethnobot. Res. 1980, 2:262

6. Kiuchi F, Iwakami S, Shibuya M, Hanaka F, Sankawa U.: Inhibition of prostaglandin and leukotrine biosynthesis by gingerols and diarylheptanoid. Chem. Pharm Bull. 40: 387-91(1992)

7. Ambiaka data Shastri Bhaishajya Ratnawali with Vidhyotini hindi commentary Chaukhambha Prakashana, Varanasi.

8. Christiane Gaudrea et. al. Antimicrob. Agents Chemother. 2007, 51(4):1524. DOI:10.1128/AAC.00905-06

Published Ahead of Print 29 January 2007.

9.http://www.promega.com/ /media/fil es/resources/education\%20and\%20trai ning/unit\%201/unit1labprotocolinstruc tor.pdf?la $=\mathrm{en}$

10. Manoj P. et.al Recent study on well known spice, Piper longum, natural product radiance vol 3 (4) July-Aug 2004.

11. http://www.dpureworld.com/store/ sunthi 


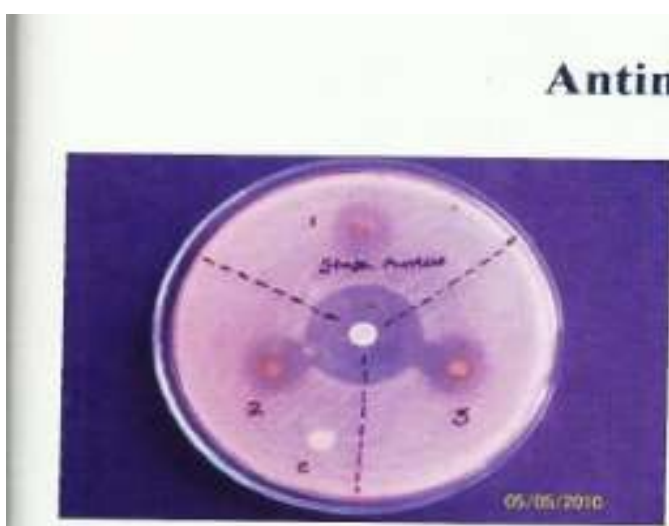

Fig. 1

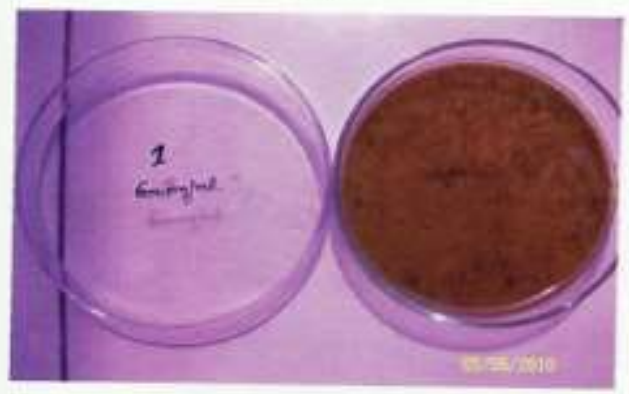

Fig. 3

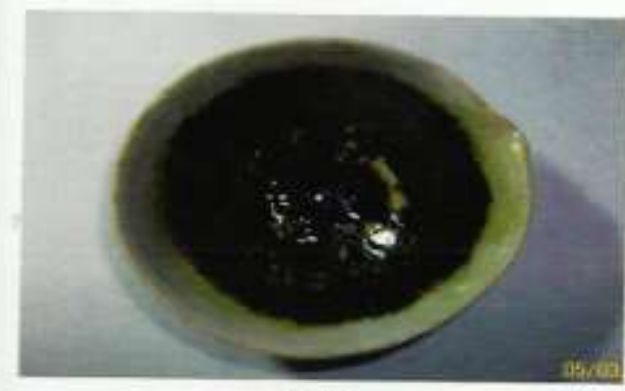

Fig. 5

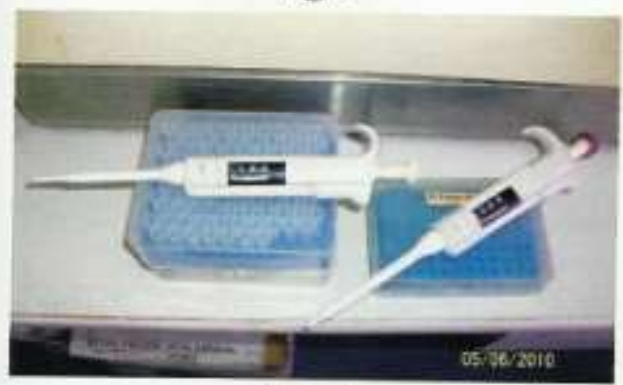

Fig 7

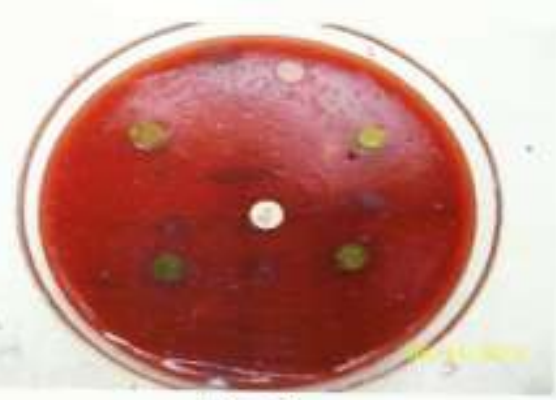

Fig. 2

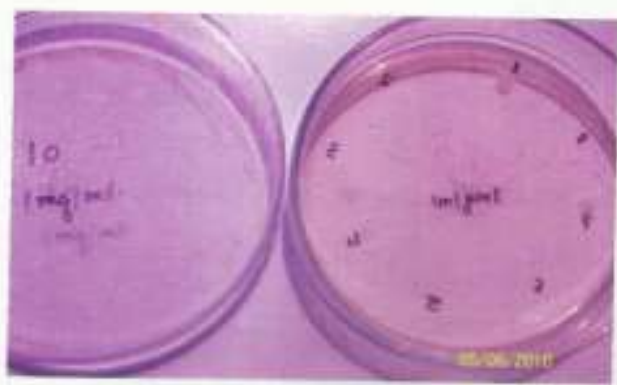

Fig. 4

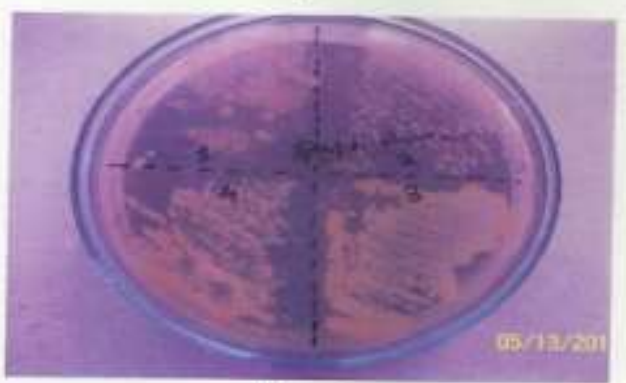

Fig. 6

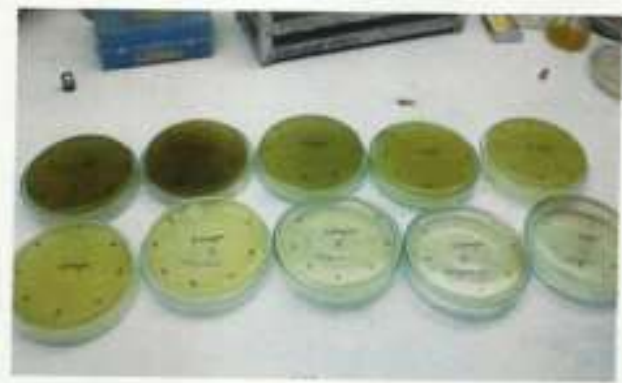

Fig 8

Fig.1 : Drugs Showing anti microbial activity against Staph. aureus compared with Ciprofloxacin

Fig.2: Drugs Showing anti microbial activity against Streptococcus pneumonia

Fig.3: Drugs Showing anti microbial activity against different bacteria's at conc of $600 \mathrm{mg} / \mathrm{ml}$ Fig.4: Drugs Showing least anti microbial activity at conc. of $1 \mathrm{mg} / \mathrm{ml}$

Fig 5: Methonolic extract prepared for the antimicrobial study

Fig 6: Different strains of Staph. aureus grown on culture media

Fig .7: Micropipettes used in study

Fig. 8 : Different petridishes having different drug conc use for antimicrobial study 